\title{
Study of Protective effect of Glutathione Peroxidase (GSH-Px), Vitamin E and Selenium on Iraqi children with Leukemia
}

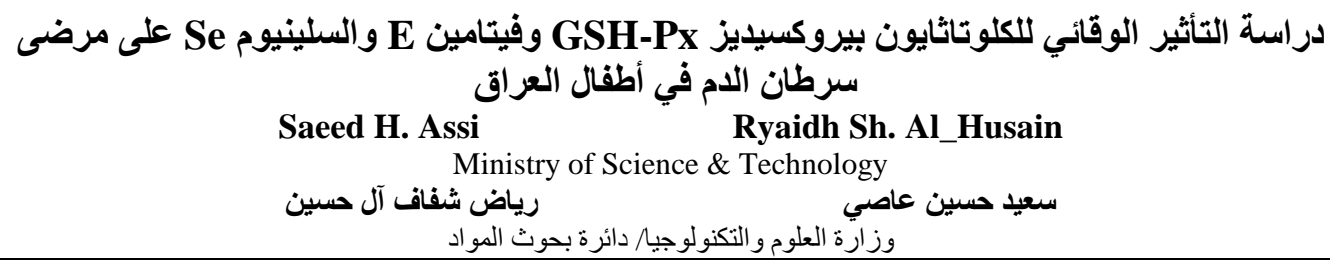

\begin{abstract}
The present study have been investigated the levels of antioxidant substances which including the enzyme glutathione peroxidase GSH-Px, vitamin E ( $\alpha$ - tocopherol), and selenium, in order to estimate their roles of preventing the body cells against oxidation processes by free radicals, hydrogen peroxides, hydrofattyperoxides, reactive oxygen species, which attack the cell membrane causing damage of these cells resulting in mutation of DNA and accidence of various cancer diseases such as leukemia. By studying 30 female and 30 male, 2-14 years old, they were divided into three groups, each group formed 20 patients. These groups included two kinds of leukemia are acute lymphoblastic leukemia (ALL) and acute myeloblastic leukemia (AML). The concentration level of glutathione peroxidase GSH-Px, and concentration level of $\alpha$ - tocopheroland selenium were significant $P<0.05$ decrease in all groups of patients male and female in both kinds of leukemia's when compared to control group.
\end{abstract}

Keywords: glutathione peroxidase, $\alpha$ - tocopherol, selenium, leukemia

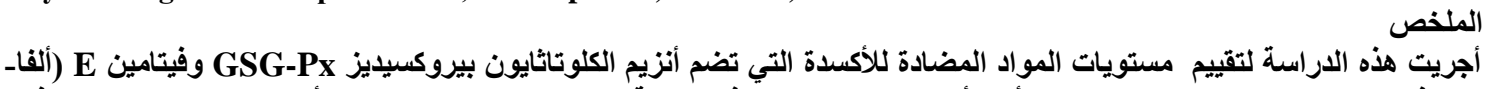

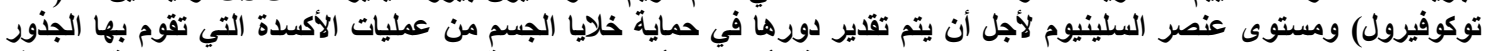

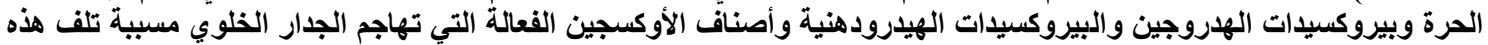

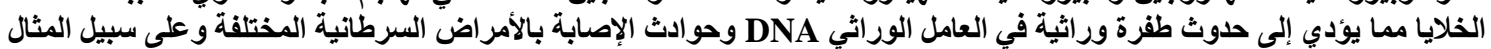

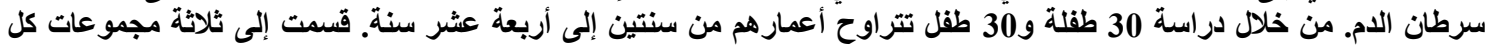

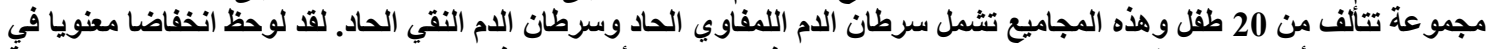

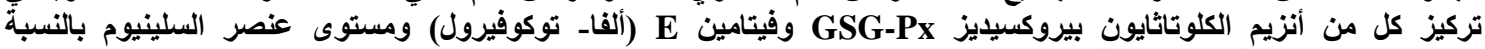
للمجموعتين بالمقارنة مع مجموعة الضبط.

الكلمات المفتاحيه: الكلوتاثايون بيروكسيديز، ألفاـ توكوفيرول، السلينيوم، سرطان الام

\section{Introduction}

Leukemia is a cancer of the tissues that produce blood cells, resulting in abnormal blood cells. Leukemia appears to be related to damage to chromosomes or genes [1]. The damage disrupts the process by which blood cells achieve their final and functional form. Leukemia is the most common kind of cancer in children. Leukemia also causes more deaths than any other form of cancer in children. There are several forms of leukemia, two of which are particularly important in children. These are usually known as ALL and AML. Acute lymphoblastic leukemia (ALL) is the most common form in children and represents $78 \%$ of cases of leukemia [2]. (ALL is also called acute lymphocytic leukemia.). Scientists believe that this pattern means that two genetic changes are needed to cause the disease and that one occurs before a child is born. Acute non-lymphocytic leukemia is the second most common form of leukemia in children and represents $19 \%$ of cases. It is also called acute myelogenous leukemia (AML). Glutathione Peroxidase (GPx. EC 1.11.1.9) represents an enzyme family with peroxidase activity whose main biological role is to protect the organism from oxidative damage. It helps prevent lipid peroxidation of cellular membranes by removing free peroxide in the cell. [3] It plays the important role of protecting cells from potential damage by free radicals, form edbyperoxide decomposition [4]. Low levels of ROS are indispensable in many biochemical processes, including intracellular messaging in the cell differentiationand cell progressionor the arrest of growth, apoptosis [5],immunity[6], and defenseagainst micro-organisms [6,7]. In contrast, high doses and/or inadequate removal of ROS result in oxidative stress, which may cause severe metabolic malfunctions and damage to biological macro molecules [9-11]. The selenium-containing peroxidase glutathione peroxidase (EC1.11.1.19) containsa single selenocysteine (Sec) residue in each of the four identical subunits, which is essential for enzyme activity [12]. GPX(80kDa) catalyses the 
reduction of hydroperoxides using GSH, thereby protecting mammalian cells against oxidative damage. In fact, glutathione metabolism is one of the most essential antioxidative defense mechanisms $[13,15]$.

GPx

\section{$\mathrm{ROOH}+2 \mathrm{GSH} \longrightarrow \mathrm{ROH}+\mathrm{GSSG}+\mathrm{H}_{2} \mathrm{O}$}

Vitamin E ( $\alpha$-tocopherol) is low molecular compound that exhibit high biological activity against oxidants and free radicals[15,16]. This is found in fats and fatty food components of both vegetable and animal origin. This substance, absorbed by blood via the lymphatic system, reach the liver and fatty tissues where it is stored. Vitamin $\mathrm{E}$ is a mixture of compounds containing four tocopherols $(\alpha, \beta, \gamma$, and $\delta$ ) and four to cotrienoles, including the most active $\alpha$-tocopherol. Vitamin E prevents oxidative damage to cellular structures and tissues through breaking reactions of free radicals, participates in the maintenance of an appropriate structure of cellular membranes, inhibits the generation of micro clots, and blocks the production of nitrosamines. Epidemiological studies evidence the association between tocopherol concentration in blood andlor its dietary intake, and mortality from neoplastic diseases [17]. Recent cancer epidemiological studies have also suggested an anti neoplastic activity by some forms of selenium. Leukemia is a type of cancer of the blood or bone marrow characterized by an abnormal increase of white blood cells[18]. Leukemia results from somatic mutations in the DNA. Certain mutations produce leukemia by activating on cogenes or deactivating tumor suppressor genes, and thereby disrupting the regulation of cell death[19]. These mutations may occur spontaneously or as a result of exposure to radiation or carcinogenic substances, and are likely to be influenced by genetic factors [20].

This work aims at estimate the levels of glutathione peroxidase enzyme, vitamin $\mathrm{E}$ and selenium in blood serum for leukemia's patients and deduce any differences in their concentrations from normal values.

\section{Materials and Methods}

\section{Chemical Reagents}

Glutathione peroxidase (Sigma), DI- $\alpha$-Tocopherol (Sigma), Selenium(Merck),95\%n-hexane and ethyl acetate (fluka) for high performance liquid chromatography (HPLC), 99.8\% ethyl alcohol (fluka) were used in the study.

\section{Methods}

\section{1- Estimation of serum glutathione peroxidase}

Glutathione peroxidase was assayed by method. kit(Randox Laboratories Ltd., UK)( Cat. No. RS 505).This method were describe by (paglia and valentine, 1967) [21]. Which based on the fact that., glutathione peroxidase (GSH-Px) catalyses the oxidation of glutathione(GSH) by cumin hydroperoxide. In the presence of glutathione reductase (GR) and NADPH, the oxidized glutathione (GSSG) is immediately converted to the reduced form with a concomitant oxidation of NADPH to NADP. Then decrease in absorbance at $340 \mathrm{~nm}$ is measured calorimetrically.

\section{2-Assessment of serum vitamin $\mathbf{E}$}

$\alpha$-tocopherol, were measured simultaneously by high performance liquid chromatography (HPLC) in three groups of children: 20 healthy children (10 males and 10 females), 20 children (10 males and 10 females) with acute myeloblastic leukemia (AML) and 20 children(10 males and 10 females) with acute lymphoblastic leukemia (ALL) at Medical City/ Hemay atAlatfal Hospital/ On cological Department. Measurement of vitamin E by HPLC ,Blood samples were collected from children to measure total serum vitamin E Participants were not required to fast for blood collection. Blood was collected via venipuncture, All tubes were protected from light, allowed to clot, centrifuged at $3000 \mathrm{rpm}$ for $10 \mathrm{~min}$, and then stored at $-80 \mathrm{oC}$ until thawed for analyses by high performance liquid chromatography (HPLC) . Briefly, the method utilizes a reversed- phase HPLC technique that shows a clear resolution of Vit E. The mobile phase is an acetonitrile extract of serum by solid phase extraction C18/Ods $4.6 * 25$.wave (295nm), HPLC was performed using a Shimadzu LC-2010AHT system with Shimadzu LC-2010 pump (Japan). 


\section{3-Determination of serum selenium}

The concentration of selenium in blood serum was measured by Shimadzu AA-670 flameless atomic absorption spectrophotometer at wavelength $196.0 \mathrm{~nm}$. Serum specimens were diluted two fold with deionized distilled water. A mixture of $(0.1 \% \mathrm{Ni}+2+0.1 \% \mathrm{Mg}+2+0.1 \% \mathrm{Cu}+2)$ as nitrate, as matrix modifier was added to both standard solutions and serum samples. Instrumental and experimental conditions were establishment. set of standard solution of Se was prepared ( 20,40,60,80,100,120 ng/ml), calibration curve have been plotted.

\section{Statistical Analysis}

Data were presented as mean \pm standard deviation (SD). The statistical analysis of data was done by using Excel program and SPSS program (statistical package for social Science Version 11)., data between the groups were compared with Student's $t$ test for continuous variables and chi-square t-test for continuous variables. Mann-Whitney's U-test was used for variables without normal distribution. A two-tailed Pvalue of $<0.05$ was considered significant.

\section{Results}

Figure (1) shows HPLC chromatograms for $\delta, \gamma$, and $\alpha$-tocopherols and tocopherol acetate.

The glutathione peroxidase (GSH-Px) in the serum of both groups of patients AML \&ALL children revealed significantly difference, decreased $\mathrm{p}<0.05$ for both groups of patients compared with control groups. The vitamin E \{alpha- tocopherol) concentration in the blood serum were significantly difference, decreased $\mathrm{p}<0.05$ for both groups of patients compared with control groups. Finely the selenium concentrations in the blood serum were highly decreased significantly $\mathrm{p}<0.001$ for both groups of patients compared with control groups. These results have been shown in Tables $(1,2)$.

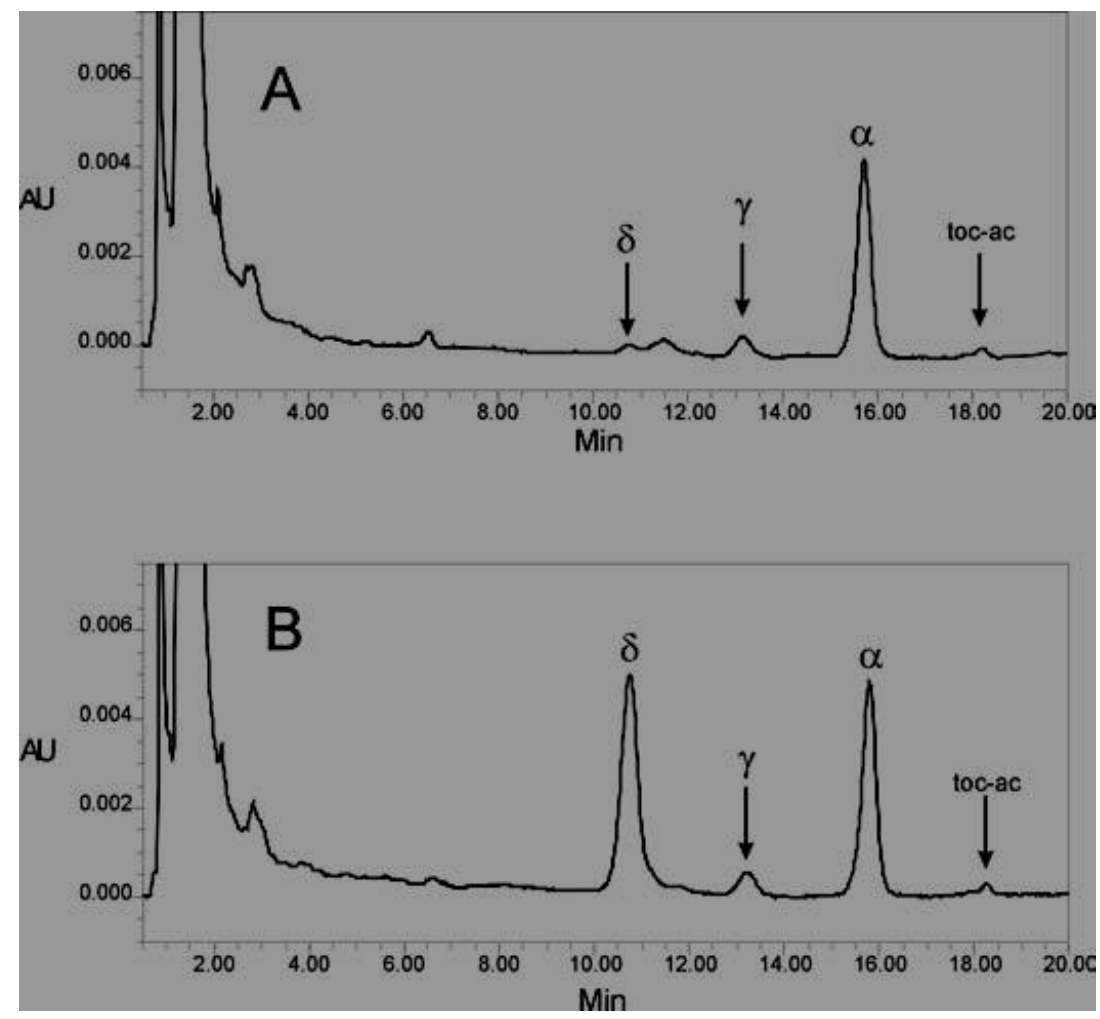

Fig.( 1): Chromatograms at $295 \mathrm{~nm}$ of different forms of vitamin $\mathrm{E}$ extracted from human blood serum using HPLC Method I. Extraction conditions are as described in the experimental section. A. serum sample. B. The same serum sample with $7 \mu \mathrm{g} \mathrm{mL}^{-1} \delta$ tocopherol. Arrows indicate the retention times for $\delta, \gamma$, and $\alpha$-tocopherols and tocopherol acetate. 
Table ( 1 ): Serum levels of Glutathione peroxidase, vitamin $\mathbf{E}$ and Selenium in males/ females children with acute myeloblastic leukemia (AML). Mean \pm SD

\begin{tabular}{|c|c|c|c|c|c|}
\hline Compound & $\begin{array}{c}\text { Children } \\
\text { withAML } \\
\text { No.=20 (male) }\end{array}$ & $\begin{array}{c}\text { ChildrenwithAML } \\
\text { No.=20(female) }\end{array}$ & $\begin{array}{l}\text { Control } \\
\text { group } \\
\text { No.=20 } \\
\text { (male) }\end{array}$ & $\begin{array}{c}\text { Control group } \\
\text { No.=20(female) }\end{array}$ & P. value \\
\hline $\begin{array}{c}\text { Glutathione } \\
\text { peroxidasemmol/I }\end{array}$ & $0.645 \pm 1.28$ & $0.615 \pm 1.22$ & $0.786 \pm 0.75$ & $0.736 \pm 0.68$ & $\mathrm{p}<0.05$ \\
\hline$\mu$ Tocopherolmol/l & $31.72 \pm 0.79$ & $31.02 \pm 0.63$ & $32.69 \pm 0.92$ & $32.37 \pm 0.86$ & $p<0.05$ \\
\hline Seleniumng/ml & $90.28 \pm 16,26$ & $90.28 \pm 16,26$ & $108.92 \pm 22.4$ & $100.50 \pm 22.4$ & $\mathrm{p}<0.001$ \\
\hline
\end{tabular}

Table( 2): Serum levels of Glutathione peroxidase, vitamin $\mathbf{E}$ and Selenium in males/ females child renwit hacutelympho blastic leukemia(ALL).Mean \pm

\begin{tabular}{llllll}
\hline \multicolumn{1}{c}{ Compound } & $\begin{array}{c}\text { Children with } \\
\text { ALL } \\
\text { No.=20 }(\text { male })\end{array}$ & $\begin{array}{c}\text { Children with } \\
\text { ALL } \\
\text { No.=20(female) }\end{array}$ & $\begin{array}{c}\text { Control group } \\
\text { No.=20 (male) }\end{array}$ & $\begin{array}{c}\text { Control group } \\
\text { No.=20(female) }\end{array}$ & P. value \\
& & & & \\
\hline $\begin{array}{c}\text { Glutathione peroxidase } \\
\text { mmol/l }\end{array}$ & $\mathbf{0 . 6 2 5} \pm \mathbf{0 . 9 8}$ & $\mathbf{0 . 6 9 5} \pm \mathbf{0 . 7 2}$ & $\mathbf{0 . 7 8 6} \pm \mathbf{0 . 7 5}$ & $\mathbf{0 . 7 3 6} \pm \mathbf{0 . 6 8}$ & $\mathrm{p}<0.05$ \\
$\begin{array}{c}\mu \text { Tocopherolmol/l } \\
\text { Seleniumng/ml }\end{array}$ & $\mathbf{3 0 . 8 4} \pm \mathbf{0 . 7 2}$ & $\mathbf{3 0 . 2 4} \pm \mathbf{0 . 6 6}$ & $\mathbf{3 2 . 6 9} \pm \mathbf{0 . 9 2}$ & $\mathbf{3 2 . 3 7} \pm \mathbf{0 . 8 6}$ & $\mathbf{p}<\mathbf{0 . 0 5}$ \\
\hline
\end{tabular}

\section{DISCUSSION}

Glutathione peroxidase is a selenium-containing antioxidant enzyme that reacts with hydrogen peroxide and soluble fatty acid hydroperoxides, thereby helping to maintain redox balance within cells. Serum levels of glutathione peroxidase have been found to be reduced in various cancers including prostate, thyroid, colorectal, breast and gastric cancers. Tumor growth results in oxidative stress, accompanied by an increase in reactive oxygen species (ROS). ROS serve as secondary messenger molecules and may result in increased cellular proliferation, an increase in genetic mutations and overall genetic instability, increased cellular invasion and angiogenesis [22]. ROS are also known to stimulate pathways that may lead to development of drug resistant in cancer cells [23]. Higher levels of ROS are, however, toxic to cells and cancer treatments often employ strategies to increase ROS production[24]. Increases in the levels of ROS also lead to the increase in transcription of antioxidant enzymes including catalase, superoxide dismutase, glutathione-S-transferase, and glutathione peroxidase [25]. The national center of cancer in iraq found that there was an increased incidence of leukemia in Iraqi children for years (19752000) [26].

Reactive oxygen species (ROS) are the main cause of most kinds of cancers which encompass all highly reactive oxygen containing molecules, including free radicals [27]. Some of ROS are defined as a free radicals, any atom or molecules having an unpaired (single) electron in its outer shells (covalent orbitals) ,for example ( $\left.\mathrm{O}_{2}, \mathrm{OH}, \mathrm{COO}, \mathrm{CO}\right)$, and others are not radicals but active metabolites of oxygen, as $\left(\mathrm{H}_{2} \mathrm{O}_{2}, \mathrm{HOCl}\right)$. ROS formation sources are mitochondrial respiratory chain, phagocytes, redox reactions, radiation exposure, cigarette smoke, environmental pollution. Main ROS are super oxide radical $\left(\mathrm{O}_{2}{ }^{-}\right)$, hydrogen peroxide $\left(\mathrm{H}_{2} \mathrm{O}_{2}\right)$, hydroxyl radical $(\mathrm{OH})$, nitric oxide $(\mathrm{NO})$, singlet oxygen $\left(\mathrm{O}^{-}\right)$. A first line body defense against oxidative stress produced by generation of free radicals and reactive oxygen species ROS are antioxidant substances ( any substance which delays or inhibits oxidative damage to a target molecule [28,29].If given with omega 3 fatty acids of fish oil, it may prolong survival in patients with generalized malignancy( Gogos, et al., 1998) [30]. There is a debate about the concurrent use of antioxidants with cytotoxic therapies (Moss, 2006) [31]. It is true that much remain unknown concerning antioxidants, their mode of action and possible interaction. New trends in treatment of leukemia are supplementation of antioxidants for patients to alleviate treatment toxicities and to improve long-term outcomes, but little is known about the efficacy and safety of antioxidants use during cancer treatment (Ladas et al., 2004) [32]. Despite considerable debate about the role of antioxidant status in cancer outcomes, very few studies have assessed changes in antioxidant status an oxidative stress. (Kennedy et al., 2005) [33] found that children with ALL have altered antioxidant status at diagnosis and during 
treatment. Results of Kennedy et al., supports prior observations that children with ALL have altered antioxidant and micronutrient status at diagnosis and treatment. In the present study, the parameters have been investigated show deficiency ( lack in antioxidants substances). Our results are consistent with the results of Ray et al., (2000) [34] and Mantovani et al., (2002) [35] who found an increase of oxidative stress during incidence by leukemia as compared with controls. Our results are conclude that the effective role of glutathione peroxidase GSH-Px, vitamin E, and selenium which represent antioxidant substances in reducing reactive oxygen species, hydrogen peroxide, hydrofatty peroxides, and free radicals. However, high levels of intracellular ROS can lead to increased DNA mutations that have been associated with increased carcinogenesis.

Selenium is an essential trace element and it is well known that selenium is necessary for cell culture. However, the mechanism underlying the role of selenium in cellular proliferation and survival is still unknown. The present study using Jurkat cells showed that selenium deficiency in a serum-free medium decreased the selenium-dependent enzyme activity (glutathione peroxidases and thioredoxin reductase) within cells and cell viability. To understand the mechanism of this effect of selenium, we examined the effect of other antioxidants, which act by different mechanisms. Vitamin E, a lipid-soluble radicalscavenging antioxidant, completely blocked selenium deficiency-induced cell death, although $\alpha$ tocopherol (biologically the most active form of vitamin E) could not preserve selenium-dependent enzyme activity. Other antioxidants, such as different isoforms and derivatives of vitamin E, BO-653 and deferoxamine mesylate, also exerted an inhibitory effect. However, the water-soluble antioxidants, such as ascorbic acid, $N$-acetyl cysteine, and glutathione, displayed no such effect. Dichlorodihydro fluorescein (DCF) assay revealed that cellular reactive oxygen species (ROS) increased before cell death, and sodium selenite and $\alpha$-tocopherol inhibited ROS increase in a dose-dependent manner. The generation of lipid hydroperoxides was observed by fluorescence probe diphenyl-1-pyrenylphosphine (DPPP) and HPLC chemiluminescence only in selenium-deficient cells. These results suggest that the ROS, especially lipid hydroperoxides, are involved in the cell death caused by selenium deficiency and that selenium and vitamin $\mathrm{E}$ cooperate in the defense against oxidative stress upon cells by detoxifying and inhibiting the formation of lipid hydroperoxides. The results of this study are in agreement with some studies demonstrating low Se levels in children with cancer [36-42].

\section{Conclusion}

Present study indicates that glutathione peroxidase GSH-Px, vitamin E, and seleniumphysiologically serves as a first line of defense reducing ROS to harmless species prior to their entry into the cell. Our results and other Epidemiological studies prove that there was an increased incidence of leukemia in Iraqi children for recent years.

\section{References}

1. NCI. Cancer Rates and Risks. (1996). National Institute of Health, National Cancer Institute, Division of Disease Prevention and Control, Cancer Statistics Branch, NIH Publication, Fourth Edition. No. 96-691.

2. Smith, M.A., Ries, L.A.G., Gurney, J.G., Ross, J.A. Leukemia. In: Ries, LAG, Smith, M.A., Gurney, J.G, Linet, M., Tamra, T., Young, J.L., Bunin, G.R., eds. (1999). Cancer Incidence and Survival Among Children and Adolescents: United States SEER Program1975-1995. Bethesda Md: Cancer Statistics Branch, Cancer Surveillance Research Program, Division of Cancer Control and Population Sciences, National Cancer Institute. 17-34.

3. Zhou, J.F., Chen, J.X., Shen, H.C., Cai, D. (2002). Abnormal reactions of free radicals and oxidative damages in the bodies of patients with chronic glomerulonephritis. Biomed. Environ. Sci. 3:233- 44

4. Ursini, F., Maiorino, M., Brigelius, F.R., Aumann, K.D., Roveri, A., Schomburg, D., Flohe, L. (1995). Diversity of glutathione peroxidases. Methods in Enzymology. 252:38-53.

5. Hurst, R., Bao, Y.,Jemth, P., Mannervik, B.,Williamson, G. (1997). Phospholipid hydroperoxide glutathione peroxidase activity of ratclass. The taglutathione transferaseT2-2. Biochem,Soc.Trans. 25:S559.

6. Jornot, L., Petersen, H., Junod, A.F. (1998). Hydrogen peroxide-induced DNA damage is independent of nuclear calcium but dependent on redox-activeions. Biochem. J.335:85-94.

7. Mills, E.M., Takeda, K.Yu., Z.X., et.al. (1998). Nerve growth factor treatment prevents the increase in superoxide produced by epidermal growth factorin PC12cells. J. Biol. Chem. 273:22165-8.

8. Ghosh, J., Myers, C.E. (1998). Inhibition of arachidonate5-li-poxygenase triggers massive apoptosis in human prostate cancer cells. Proc. Natl. Acad. Sci. 95: 13182-7. 
9. Yin, G.Y., Yin, Y.F., He, X.F. (1995). Effect of zhuchunpill on immunity and endocrine function of elderly with kidney-yang deficiency.Chung Kuo Chung Hsil Chieh HoTsa Chih.15:601-3.

10. Bae, Y.S. Kang, S.W. Seo, M.S.et.al. (1997). Epidermal growth factor (EGF)- induced generation of hydrogen peroxide. J. Biol. Chem. 272: 217-21.

11. Meyer, D.F., Nealis, A.S. Macphee, C.H. et.al. (1996). Time-course studies by synchrotron X-ray solutions cattering of the structure of human low-density lipoprote induring $\mathrm{Cu}^{+}$-induced oxidation in relation to changes in lipid composition. Biochem. J.319: 217-27.

12. Low density lipoprote in less at acidic pH. FEBS. Lett. 434: 317-21.

13. Rikans, L.E., Horn brook, K.R. (1997). Lipid peroxidation, anti-oxidant protection and aging. Biochim. Biophys. Acta. 1362:116-27.

14. Asherio, Halli well, B. (1994). Free radicals and antioxidants: a personal view. Nutr. Rev. 52, 253.

15. Nakazawa, H. Genka, C. Fujishima, M. (1996). Pathological aspects of active oxygens $\backslash$ free radicals. Jpn. J. Physiol. 46, 15.

16. Malila, N. Virtamo, J. Virtanen, M. Pietinen, P. Albanes, D. Teppo, L. (2002). Dietary and serum $\alpha-$ tocopherol, $\beta$-carotene and retinol, and risk for colorectal cancer in male smokers. Eur. J. Clin. Nutr. 56, 615 .

17. Hoffbrand, A.V. Moss, P.A.H. and Pettet, J.E. "Essential Haematology", Blackwell, $5^{\text {th }}$ ed., 2006.

18. Jameson, J. N. St. C. Dennis, L. Kasper, Harrison, Tinsley, Randolph, Braunwald, Eugene; Fauci, Anthony. S. Hauser, Stephen, L; Longo, Dan L. (2005). Harrison's principles of internal medicine. New York: McGraw-Hill Medical Publishing Division.

19. Gribben, J.G. (January 2008). "Stem cell transplantation in chronic lymphocytic leukemia". Biol. Blood Marrow Transplant. 15 (1 Suppl): 53-8.

20. Azad, M.B. Chen, Y. Gibson, S.B. (2009). Regulation of autophagy by reactive oxygen species (ROS): Implications for cancer progression and treatment”. Antioxid. Redox. Signal.1:777-790.

21. Paglia, D. E. and Valentine, W.N. (1967). Studies on the quantitative and qualitative characterization of erythrocyte glutathione peroxidase. J.Lab. Clin. Med. 70(1): 158-169.

22. Pelicano, H., Carney, D., Huang, P. (2004). ROS stress in cancer cells and therapeutic implications. Drug Resist. Update. 7:97-110

23. Harris, A.L. (2002). Hypoxia-a key regulatory factor in tumor growth. Nat. Rev. Cancer. 2: 38-47.

24. Tertil, M. Jozkowicz, A. Dulak, j. (2010). Oxidative stress in tumor. angiogenesis-therapeutic targets. Curr. Pharm. Des.16:3877-3894.

25. Howie, A.F. Walker, S.W. Aakesson, B. Arthur, J.R., Beckett, G.J. (1995). Thyroidal extra cellular glutathione peroxidase: a potential regulator of thyroid-hormone synthesis”. Bio. chem. J. 308: 713-717.

26. Ministry of Health, National center of cancer in Iraq:( 1998, 1999, 2000).

27. Halliwell, B. Gutteridge, J. M. C. (1989). Free radical in biology and medicine.Oxford University Press, New York.

28. R.W. Owen. (2000). Generation of reactive oxygen species by the faecalmatrix, Emergency Med. J. Gut. 46: 255.

29. Bendich, A. and Machlin, L. J. (1988). Safety of oral intake of vitamin E. Am. J.Clin. Nutr. 48(3):612619.

30. Gogos, C. A., Ginopoulos, P., Salsa, B., Apostolidou, E., Zoumbos, N. C. and Kalfarentzos, F. (1998). Dietary omega-3 polyunsaturated fatty acids plus vitamin E restore immunodeficiency and prolong survival for severely ill patients with generalized malignancy: a randomized control trial. Cancer. 82 (2): $395-402$

31. Moss, R.W. (2006). Should patients undergoing chemotherapy and radio therapy be prescribed antioxidants? Integr. Cancer Ther. 5(1):63-82.

32. Ladas, E.J., Jacobson, J.S., Kennedy, D.D., Teel, K., Fleischauer, A. and Kelly, K. M. (2004). Antoxidants and cancer therapy: a systematic review. J. Clin. Oncol. 22(3):517-528.

33. Kennedy, D. D., Ladas, E. J., Rheingold, S.R., Blumberg, J. and Kelly, K.M. (2005). Antioxidant status decreases in children with acute lympho blastic leukemia during the first six months of chemotherapy treatment". Peditr. Blood Cancer. 44(4):378-385.

34. Ray, G., Batra, S., Shukla, N.K., Deo, S., Raina, V., Ashok, S. and Husain, S.A. (2000). Lipid peroxidation, free radical production and antioxidant status in breast cancer. Breast cancer RES. Treat. 59(2):163-170.

35. Mantovani, G., Maccio, A., Madeddu, C., Mura, L., Gramignano, G., Lusso, M.R., Mulas, C. Mudu, M.C., Murgia, V., Cambony, P., Massa, E., Ferreli, L., Contu, P., Rinaldi, A., Sanjust, E., Atzei, D. and Elsener, B. (2002). Quantitative evaluation of oxidative stress, chronic inflammatory indices and lepton in cancer patients: correlation with stage and performance status". Int. J. Cancer. 98(1):84-91.

36. Mikac, D. M. Ferenec, D. and Tiefenbach, A. (1990). Serum selenium levelsin untreated children with acute lymphoblastic leukemia. I. J. Trace Elem. Electrolytes Health Dis. 4: 7-10. 
37. Gromadzinska, J., Wasowicz, W., Sklodowska, M., Perek, D. and Popadiuk, S. (1988). Glutathione peroxidase activity, selenium and lipid peroxides levels in blood of cancer children. Ann. Clin. Res. 20: 177-183.

38. Wasowicz, W., Gromadzinska, J., Sklodowska, M. and Popadiuk, S. (1994). Selenium concentration and glutathione peroxidase activity in blood of children with Cancer. J. Trace Elem. Electrolytes Health Dis. 8:53-57.

39. Pazirandeh, A. Assadi, N.M. and Vossogh, P. (1999). Determination of selenium in blood serum of children with acute leukemia and effect of chemotherapy on serum selenium level. J. Trace Elem. Med. Biol. 13: 242-246

40. Kauf, E., Fuchs, D. Winnefeld, K., Hermann, J. and Zintl, F. (1997). Blood selenium content after conditioning and during the course of bone marrowtransplantation in children with malignant diseases. Med. Klin. 92(3 Suppl):46-47

41. Popadiuk, S., Korzon, M., Wasowicz, W., Gromadzi’nska, J.S.k._lodowska, M. etal. (1995). Selenium, glutathione peroxidase and TBARS in plasma of children with malignant diseases of the hematopoietic system. Pediatr. Pol. 70:313-317.

42. Koskelo, E.K. (1990). Serum selenium in children during anti-cancer chemotherapy. Eur. J. Clin. Nutr. 44: 799-802. 